\title{
Zmiany kierunków użytkowania gruntów ze szczególnym uwzględnieniem terenów przemystowych w wielkich miastach Polski i ich otoczeniu w latach 2005 i $2009-2014$
}

\section{Land Use Changes with Particular Focus on Industrial Lands in Polish Major Cities and Their Surroundings in the Years 2005, 2009 to 2014}

\begin{abstract}
Streszczenie: Niniejszy artykuł dotyczy szeroko dyskutowanej w kręgach naukowych i politycznych w Polsce problematyki suburbanizacji, zmian funkcji i struktury przestrzennej miast oraz otaczających ich obszarów zewnętrznych. Dyskusja i badania odnoszące się do tego zjawiska, obecne w wielu publikacjach, koncentrują się głównie na zagadnieniach społecznych, demograficznych i ekonomicznych. Poruszane jest w nich zagadnienie dynamiki zjawisk na styku miasta rdzeniowego i obszaru zewnętrznego. Sam obszar (strefa) zewnętrzny delimitowany bywa w różny sposób przez różne instytucje, brakuje konsensusu w tej sprawie. Nazywany jest obszarem funkcjonalnym, metropolitalnym, regionem miejskim, suburbiami czy bardziej tradycyjnie i całościowo - aglomeracją. Wśród wielu kwestii dotyczących relacji układu obszar centralny (core city) - obszar zewnętrzny szczególnie interesująco z punktu widzenia nauki przedstawia się proces deindustrializacji obszaru centralnego i rozwoju jego funkcji na obszarach otaczających. Głównym celem artykułu jest odpowiedź na poniższe pytania. Czy i w jakim zakresie w relacji miasto rdzeniowe - obszar zewnętrzny dochodzi do zmian w sposobie użytkowania gruntów? I w węższym ujęciu - czy potwierdzają się obserwacje dotyczące deindustrializacji miast rdzeniowych, zmian zajmowanych przestrzeni przemysłowych i przenoszenia funkcji gospodarczych na tereny podmiejskie i otaczające oraz powstawania nowych takich funkcji? W badaniach posłużono się danymi Głównego Urzędu Geodezji i Kartografii (GUGiK) z lat 2009-2014 w układzie powiatów ziemskich i grodzkich. Dane liczbowe dotyczyły powierzchni i sposobu użytkowania gruntów $\mathrm{w}$ danej jednostce administracyjnej według klasyfikacji urzędowej. Dodatkowo dla miast rdzeniowych pogłębiono analizę od 2005 roku (według dostępności danych). W celu uzupełnienia analizy i dopełnienia obrazu prezentowanych zjawisk wykorzystano dane o produktywności przemysłu w układzie powiatów. Obszar zewnętrzny miast delimitowano przez wybór powiatów w otoczeniu miast rdzeniowych - w nawiązaniu do stosowanych przez Eurostat regionów metropolitalnych oraz wyznaczonych w Koncepcji Przestrzennego Zagospodarowania Kraju (KPZK) miejskich obszarów funkcjonalnych.
\end{abstract}

Abstract: This article has been placed in widely debated in scientific and political communities issues of suburbanization, changes of functions and in the spatial structure of cities and their surrounding outer areas. Discussion and research concerning this phenomenon focus mainly on social, demographic and economic issues. Dynamics of mentioned issues at the interface between the core city and the outer suburbs and exurbs are raised in the publications. Areas (zones) outside the city are delimited in different ways by different institutions. In Poland there is observed a noticeable lack of consensus in scientific as well as political dimension on criteria of such delimitations. This areas are defined like an urban functional areas, metropolitan region 
of the city, suburbs, more traditionally and holistic - agglomeration area. Particularly scientifically interesting among a number of issues concerning the relationship between central area (core city) and the area outside city borders, especially the process of moving outside central urban areas or development industrial functions in exurbs areas. This article aims to analyze and answer of the following question. What are relationships between core-city- and exurbs-area-concerned directions, scale and dynamics changes in land use: industrial land, housing, communications, other built-up. In a narrower sense this research is an attempt to confirm the observation of deindustrialization of core cities, measured by industrial land use. In order to achieve the goals, datasets from GUGiK (Polish Main Office for Geodesy and Cartography) for the years 2009 and 2014, data collected for land and municipal counties (poviats - NUTS level 4) have been used. Data are related to surface and land use in the administrative unit according to the official classification. In addition to the core cities more thorough analyses since 2005 (according to data availability) were made. To complete the full picture of presented phenomena, data on industrial productivity by counties were used. The exurbs area has been delimited by selecting counties surrounding the core cities - with reference delimitation of metropolitan regions based on NUTS 3 used by Eurostat and Urban Functional Areas in Poland set out in the KPZK (National Spatial Development Concept).

Słowa kluczowe: deindustrializacja; obszary funkcjonalne; obszary metropolitalne; tereny przemysłowe; urbanizacja; użytkowanie gruntów

Keywords: deindustrialisation; functional areas; industrial areas; land use; metropolitan areas, suburbanisation

Otrzymano: 18 stycznia 2016

Received: 18 January 2016

Zaakceptowano: 23 maja 2016

Accepted: 23 May 2016

\section{Sugerowana cytacja / Suggested citation:}

Rudewicz, J. (2016). Zmiany kierunków użytkowania gruntów ze szczególnym uwzględnieniem terenów przemysłowych w wielkich miastach Polski i ich otoczeniu w latach 2005 i 2009-2014. Prace Komisji Geografii Przemysłu Polskiego Towarzystwa Geograficznego, 30(2), 122-141.

\section{WSTĘP}

Miasta to obszary o dużej koncentracji ludności i wysokiej aktywności gospodarczej. Wynika z tego wiele możliwych problemów i dynamicznych zjawisk, od ekonomicznych, społecznych, przyrodniczych, technicznych, administracyjno-politycznych, po kulturowe. Miasto jest bardzo interesującym, choć trudnym przedmiotem badań. Trudność i jednocześnie pewne szersze pole badawcze wynikać może z problemu delimitacji miasta w przestrzeni. Granice miast mogą mieć charakter arytmomorficzny lub niearytmomorficzny (Chojnicki, 1988).

Granice arytmomorficzne we współczesnych realiach funkcjonowania miast stanowią prawne ograniczenie zasięgu sprawowania władzy, odpowiadające granicom administracyjnym, jednak obserwowane od dawna procesy rozlewania się miast - suburbanizacji (urban sprawl) i wzrost oddziaływania funkcjonalnego miast na zewnątrz (funkcje centralne) poszerzają zasięg ich wpływu. Zmiany przestrzennych relacji między miejscem zamieszkania a miejscem pracy mieszkańców, postępujących procesów koncentracji i dekoncentracji ludności oraz działalności gospodarczej powodują, że postrzegane terytorium miast jest większe - są to już: aglomeracja, obszar metropolitalny, region miejski. Jeśli wprowadzimy rozgraniczenie pomiędzy miastem centralnym lub też rdzeniowym i otaczającym je obszarem pozostającym w zasięgu jego oddziaływania, 
powstanie pewien układ przestrzenny. Obszar otaczający miasto formalnie składa się z jednostek samorządu terytorialnego (miast i gmin) mających własne granice arytmomorficzne, razem tworzących otoczkę miasta rdzeniowego.

Niearytmomorficznie, tzn. w sposób płynny, przebiegać może rzeczywista granica tej otoczki, stąd potrzebny jest pewien kompromis w jej delimitacji i możliwości badania z wykorzystaniem danych statystycznych. Takiego układu: miasto rdzeń - obszar otaczający dotyczy problematyka niniejszego artykułu. Głównym pytaniem, jakie przyświecało temu badaniu, było określenie, czy obserwowane od dawna deindustrializacja i procesy suburbanizacji mają swój wymiar przestrzenny w postaci zmian zajmowanych powierzchni przemysłowych (Rowthorn, Ramaswamy, 1997).

Czy potwierdzają się obserwacje dotyczące deindustrializacji miast rdzeniowych, zmian zajmowanych przestrzeni przemysłowych i przenoszenia funkcji gospodarczych na tereny podmiejskie i otaczające oraz powstawania nowych takich funkcji? W artykule porównane zostaną dwa stany z lat 2009 i 2014, z pogłębieniem analizy dla wybranych jednostek badawczych do 2005 roku. Na potrzeby badania na terytorium Polski wydzielono 14 takich układów - jednostek badawczych zbudowanych w oparciu o miasta - powiaty grodzkie i powiaty ziemskie w ich otoczeniu. Powiaty grodzkie nazywane są miastami rdzeniowymi, powiaty ziemskie z kolei, połączone w jeden teren, nazwano obszarami otaczającymi. Łącznie stanowi to 69 powiatów, w tym 28 grodzkich, i 15\% powierzchni kraju.

Wśród jednostek badawczych znalazły się także konurbacje trójmiejska oraz górnośląska, stąd wynika relatywnie duża liczba powiatów grodzkich. Dlatego występujące tam jednostki administracyjne (powiaty grodzkie) połączono w jeden obszar rdzeniowy. Do zestawu jednostek badawczych dołączono Olsztyn oraz Kielce wraz z otaczającymi je powiatami. Miasta te nie tworzą obszarów metropolitalnych i mają mniejsze znaczenie w sieci osadniczej Polski, jednak włączono je jako reprezentację dla miast do 200 tys. mieszkańców, miast „współtworzących” (Kafka, 2012). Jednostki badawcze (ryc. 1) wydzielono, wzorując się na wskazanych przez Unię Metropolii Polskich obszarach metropolitalnych oraz częściowo w nawiązaniu do miejskich obszarów funkcjonalnych opracowanych przez Instytut Geografii i Przestrzennego Zagospodarowania Polskiej Akademii Nauk (Śleszyński, 2013).

Źródłem danych o sposobie i kierunkach wykorzystania gruntów w roku 2005 (powiaty grodzkie) oraz w roku 2009 (powiaty grodzkie i ziemskie) były materiały elektroniczne udostępnione przez Ministerstwo Rozwoju Regionalnego. Ich upublicznienie związane było z opracowaniem raportu wprowadzającego Rozwój miast w Polsce przygotowanego na potrzeby przeprowadzonego przez OECD przeglądu krajowej polityki miejskiej w Polsce (Węcławowicz, Łotocka, Baucz, 2010) W raporcie tym wykorzystano projekt Instytutu Rozwoju Miast (Wierzchowski, 2009). Źródłem analogicznych danych za 2014 rok jest Bank Danych Lokalnych Głównego Urzędu Statystycznego (BDL GUS). Jeżeli chodzi o informacje o powierzchni geodezyjnej kraju według kierunków wykorzystania, to ich pierwotnym źródłem był Główny Urząd Geodezji i Kartografii, a podstawą prawną rozporządzenie Ministra Rozwoju Regionalnego i Budownictwa z 29 marca 2001 roku w sprawie ewidencji gruntów i budynków oraz jego nowelizacja z 2013 roku. 
Sprawy geodezji reguluje w Polsce ustawa z 17 maja 1989 roku - Prawo geodezyjne i kartograficzne. Swoim zakresem obejmuje ona m.in. zagadnienia: krajowego systemu informacji o terenie, ewidencji gruntów i budynków, państwowego zasobu geodezyjnego i kartograficznego, a także inwentaryzacji i ewidencji sieci uzbrojenia terenu. Wspomniany wyżej BDL GUS był także źródłem danych o wartości sprzedanej przemysłu w powiatach, które wykorzystano do obliczenia wskaźnika wartości sprzedanej z 1 ha terenów, nazywanej dalej „produktywnością”.

Ryc. 1. Zastosowane jednostki badawcze. Miasta rdzeniowe i obszary otaczające

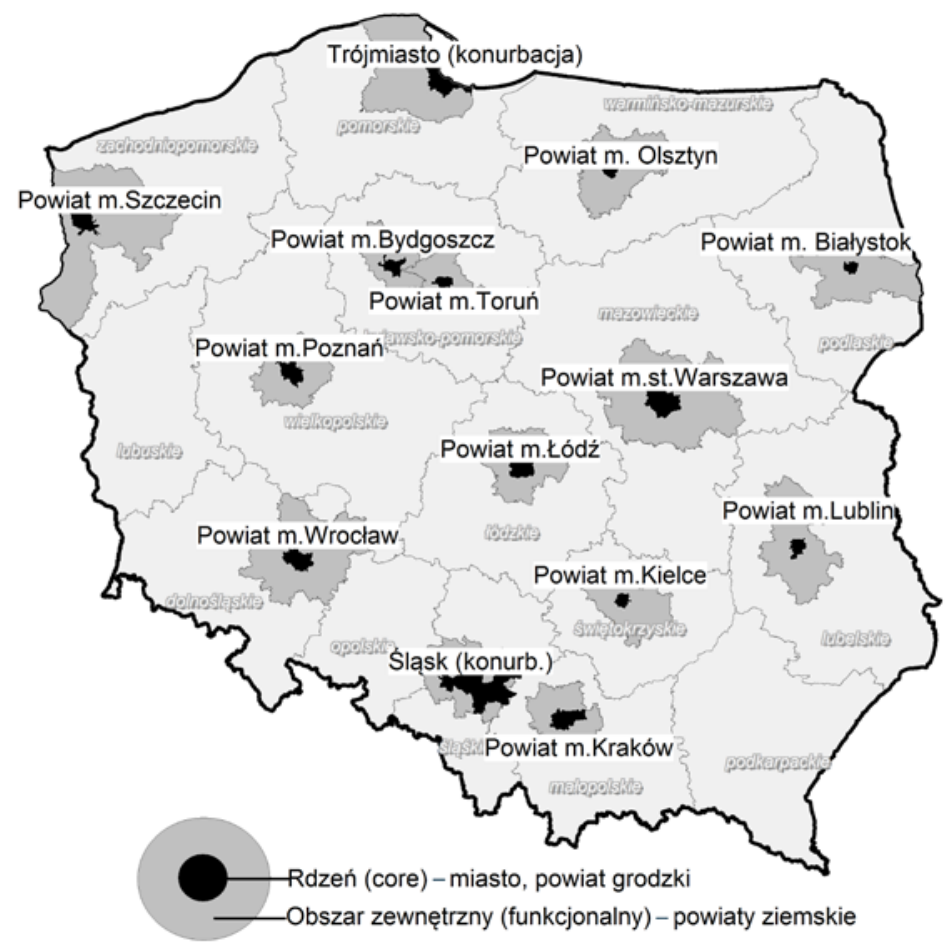

Źródło: opracowanie własne

Dane liczbowe o powierzchni w hektarach ułożone są w zbiorczych kategoriach użytkowania gruntów, np. gruntów zabudowanych i zurbanizowanych, a w ramach danej kategorii mieszczą się poszczególne tereny, np. tereny przemysłowe. Według wspomnianego rozporządzenia w sprawie ewidencji gruntów i budynków do terenów przemysłowych zalicza się „grunty zajęte pod budynki i urządzenia służące produkcji przemysłowej, a także ujęcia wody, oczyszczalnie ścieków, stacje transformatorowe, czynne hałdy i wysypiska, urządzenia magazynowo-składowe, bazy transportowe i remontowe itp.". Dane zostały poddane sumowaniu do granic jednostek badawczych, następnie zaś - analizie i zobrazowaniom kartograficznym, dokonano również porównań dynamiki względnej, bezwzględnej oraz zmian w strukturze. 
Badania powierzchni zajmowanych przez przemysł są stosunkowo często prowadzone przez geografów i koncentrują się głównie na pojedynczych przypadkach miast czy obszarów metropolitalnych, np. Struktura funkcjonalno-przestrzenna wybranych terenów przemysłowych Poznania (Staszewska, Marcinowicz, 2006). W niniejszej pracy przyjęto szerszą, ogólnokrajową perspektywę i - co za tym idzie - podejście mniej szczegółowe, a bardziej generalizujące.

\section{KONCEPTUALIZACJA I SFORMUŁOWANIE PROBLEMU}

W części wstępnej przedstawiono kształt i liczbę jednostek badawczych, w tym zaś rozdziale opisane zostaną relacje mogące zachodzić w układzie miasto (lub miasta) rdzeniowe - otoczenie. Najlepiej obrazuje te relacje poglądowy model (ryc. 2), przygotowany na podstawie literatury przedmiotu i obserwacji autora. Koncentryczny kształt modelu nawiązuje do klasycznego ujęcia E.W. Burgessa i R.E. Parka, z tym że został uproszczony do dwóch stref, a zasięg przestrzenny wraz z miastami satelickimi powiększono (Park, Burgess, McKenzie, 1925). Poniższy model nawiązuje w większym stopniu do koncepcji regionu miejskiego R.T. Formana (Forman, 2008). Podobne podejście można też spotkać w projekcie $\operatorname{COMET}^{1}$ (Bachmann, 2003). W modelu uwzględniono korzyści (i czynniki niekorzystne) aglomeracji w trzech postaciach: korzyści urbanizacji, skali i lokalizacji, a także przyciąganie informacyjne w działalności gospodarczej (Domański, 2004).

Ryc. 2. Model poglądowy relacji miasta rdzeniowego z obszarem zewnętrznym
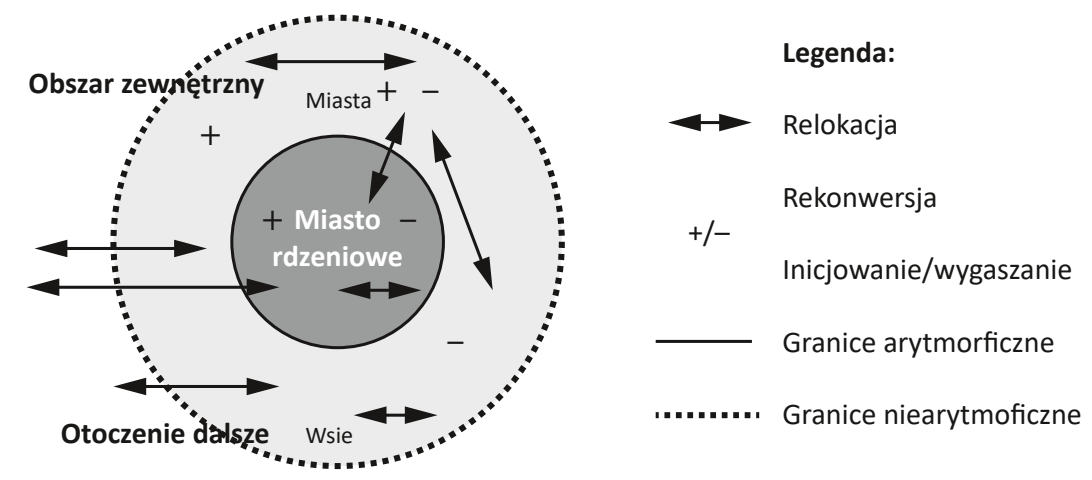

Źródło: opracowanie własne

Pomiędzy elementami modelu: miastem rdzeniowym, miastami satelickimi oraz obszarem zewnętrznym i otoczeniem dalszym, w odniesieniu do działalności gospodarczej, dochodzi do przemieszczeń i przepływów. Przemieszczenia dokonują się za pomocą sieci transportu, która wpływa na rozmieszczenie działalności gospodarczej,

${ }^{1}$ Competitive Metropolises Economic Transformation, Labour Market and Competition in European Agglomerations. 
w tym terenów przemysłowych, w sposób promienisty i koncentryczny wokół rdzenia (Domański, 2007). Na modelu (ryc. 2) zaznaczono strzałkami możliwe kierunki relokacji działalności przemysłowej.

R. Domański za B.E. Moriartym (Moriarty, 1983) podaje, że relokacja (przeniesienie) jest uwarunkowana istnieniem geograficznych różnic w koszcie produkcji. Działa wtedy efekt filtrowania w dół zakładów przemysłowych oraz hierarchicznego filtrowania w dół dla systemu miast, od większych do mniejszych, i terenów mniej zurbanizowanych w celu obniżenia kosztów. Filtrowanie przestrzenne - hierarchiczne - zachodzi także w odniesieniu do cyklu życiowego produktu (technologii). Stosując pojęcie filtru, wyjaśnić można również zmianę funkcji obiektu gospodarczego bez istotnych zmian jego kształtu przestrzennego, np. zmiana asortymentu produkcji w zakładzie przemysłowym lub zamiana działalności usługowej na przemysłową i odwrotnie. Taki rodzaj filtrowania Domański nazywa absorpcyjnym (Domański, 2004). Filtry absorpcyjne mogą powodować zmianę struktury przestrzennej, która wchłania przemiany społeczno-gospodarcze, wchłanianie to zaś może mieć różne nasilenie i być selektywne.

Cały model można umieścić w kontekście geograficznych konsekwencji postfordyzmu, a w przypadku Polski dodatkowo uwarunkowań historycznych i transformacji gospodarczej, gdzie nowe przestrzenie przemysłowe są coraz bardziej wieloośrodkowe i mniej skoncentrowane. Innym spojrzeniem na genezę procesów przestrzennych w modelu może być sprowadzenie przyczyn do czynników pull i push (Mariotti, 2005). Proces przestrzenny, jakim jest relokacja, prowadzić może do zmian w powierzchni terenów przemysłowych, chyba że dochodzi do przeniesienia na tereny o już istniejącym przeznaczeniu przemysłowym. Zmiana funkcji na danym terenie przemysłowym ma charakter rekonwersji, czyli przekształcenia. Na ogół nie musi (choć może) być ona związana ze zmianą powierzchni i może odpowiadać założeniom rewitalizacji (Sztaba, 2013). Dodając do całego obrazu przekształceń przestrzeni inicjowanie nowej działalności przemysłowej i wygaszanie istniejącej oraz odpowiadające im powstawanie i likwidowanie terenów przemysłowych, można uzyskać bilans zmian (tab. 1).

Tab. 1. Bilans bezwzględnych zmian terenów przemysłowych

\begin{tabular}{|c|c|c|c|c|}
\hline \multirow{2}{*}{\multicolumn{2}{|c|}{$\begin{array}{c}\text { Bilans } \\
\text { Relokacja/rekonwersja/inicjacja/wygaszanie }\end{array}$}} & \multirow{3}{*}{$\begin{array}{c}\begin{array}{c}\text { Miasto } \\
\text { rdzeniowe }\end{array} \\
+\end{array}$} & \multicolumn{2}{|c|}{ Obszar zewnętrzny } \\
\hline & & & \multirow{2}{*}{\begin{tabular}{|c|} 
miasto \\
+ \\
\end{tabular}} & \multirow{2}{*}{$\begin{array}{c}\text { wieś } \\
+ \\
\end{array}$} \\
\hline 1 & Rozwój równomierny & & & \\
\hline 2 & Powiększanie terenów w miastach & + & + & - \\
\hline 3 & Powiększanie terenów w rdzeniu & + & - & - \\
\hline 4 & Powiększanie terenów we wsiach & - & - & + \\
\hline 5 & Powiększanie terenów w obszarze zewnętrznym & - & + & + \\
\hline 6 & Powiększanie terenów w miastach obszaru zewnętrznego & - & + & - \\
\hline 7 & Powiększenie do wsi obszaru zewnętrznego i miasta rdzeniowego & + & - & + \\
\hline 8 & Ucieczka do otoczenia, wygaszanie w całym układzie & - & - & - \\
\hline
\end{tabular}

Źródło: opracowanie własne

Przyjąwszy, że zmiany przestrzeni są dołączane do figury geometrycznej - pierścienia kołowego wokół rdzenia, pomiędzy miastem rdzeniowym, miastami satelickimi i obszarem otaczającym oraz otoczeniem - dochodzi do kombinacji zmian w postaci 
bilansu zajmowanych terenów. Bilans terenów przemysłowych w modelu ma osiem możliwych stanów. Pierwszy to powiększanie bezwzględne terenów przemysłowych we wszystkich jego częściach - rdzeniu i obszarze zewnętrznym, zarówno w miastach, jak i na terenach wiejskich. W wyniku kolejnych kombinacji powstaje hipotetyczna sytuacja, w której kurczą się tereny zajmowane przez przemysł - dominuje relokacja na zewnątrz układu i wygaszanie działalności gospodarczej. Tereny przemysłowe mogą przejmować pojedyncze działki, mogą się one skupiać i koncentrować samoistnie lub w specjalnych strefach ekonomicznych (SSE) itp. Idąc dalej w rozważaniach teoretycznych, można rozpatrywać zaprezentowany model (tab. 1) w ujęciu dynamicznym i względnym, kiedy np. przyrost terenów przemysłowych jest szybszy w rdzeniu, a względnie wolniejszy na obszarze zewnętrznym.

\section{REGUŁY I UWAGI INTERPRETACYJNE}

Informacje o stanie zagospodarowania powierzchni uzyskać można na dwa sposoby: poprzez analizę zobrazowań satelitarnych i lotniczych - podejście teledetekcyjne (np. projektCORINE) - oraz poprzez ewidencję gruntów prowadzoną administracyjnie podejście ewidencyjne. Pomiędzy tymi dwiema metodami istnieje zależność, polegająca na wykorzystywaniu danych pozyskanych drogą zdalną do inwentaryzacji i aktualizacji ewidencji. Oba sposoby mają szereg zastosowań, właściwości i dokładności. O podejściu teledetekcyjnym pisał B. Zagajewski (2013). Zwraca on uwagę na dużą przydatność wielospektralnych zobrazowań do szczegółowej inwentaryzacji zagospodarowania terenu. Dokładność klasyfikacji pokrycia terenu, pomimo użycia metod automatyzacji, algorytmów i sieci, wynosi 80-90\%. Autor podkreśla wysoki koszt uzyskania takich danych, a także ich brak w odniesieniu do całego kraju, mimo ich ogromnej przydatności w badaniach zagospodarowania przestrzennego, wciąż niedocenianego w Polsce.

Ewidencja gruntów i budynków, której podstawą jest zaliczenie działki do odpowiedniej kategorii, również jest obarczona pewnymi błędami. Obecnie jednak brak jest szacunku takiego błędu, chociaż dane z poszczególnych kategorii użytkowania gruntów sumują się do wartości dla całego obszaru w granicach administracyjnych. Najwyższa Izba Kontroli zwraca uwagę na brak systematycznego aktualizowania ewidencji na podstawie kontroli, którą objęto 22 jednostki - urzędy miast na prawach powiatu i starostwa powiatowe. Stwierdzone nieprawidłowości pojawiają się, gdy proces inwestycyjny trwa długo i grunty rolne przeznaczone pod zabudowę mieszkaniową lub działalność przemysłową nie są zaliczane do odpowiedniej kategorii. Ma to swoje konsekwencje podatkowe ${ }^{2}$, gdyż pobierany jest od tych gruntów podatek rolny, zamiast znacznie wyższego podatku od nieruchomości (Wyłączanie gruntów..., 2012).

Zaliczenie działki do odpowiedniej kategorii użytkowania gruntu odbywa się poprzez samodzielne jej zgłoszenie do starostwa powiatowego przez właściciela. Ewidencję gruntów i budynków (kataster nieruchomości) prowadzą starostowie. Nadzór nad działalnością starostów w tym zakresie sprawują w imieniu wojewody wojewódzcy

${ }^{2}$ Dane zawarte w ewidencji stanowią podstawę: planowania gospodarczego, planowania przestrzennego, wymiaru podatków i świadczeń, oznaczania nieruchomości w księgach wieczystych, statystyki publicznej, gospodarki nieruchomościami. 
inspektorzy nadzoru geodezyjnego i kartograficznego. Interpretując dane zawarte w artykule, należy mieć na względzie ich charakter i dokładność oraz fakt, że rozporządzenie dotyczące klasyfikacji terenów przemysłowych uległo pewnym zmianom, jednakże zasadnicze kategorie klasyfikacji gruntów nie zmieniły się. Tereny podlegające przekształceniu w trakcie zmian inwestycyjnych są zaliczane do użytków gruntowych - „zurbanizowane tereny niezabudowane lub w trakcie zabudowy”. Problemem w interpretacji mogą być także grunty, które utraciły dotychczasowe funkcje przemysłowe ${ }^{3}$. Wyjaśnienia dotyczące klasyfikowania gruntów i terenów stosowanych w artykule dostępne są w treści rozporządzenia. W niniejszej pracy będą stosowane pozostałe kategorie terenów.

Interpretując dane w odniesieniu do zastosowanych w artykule jednostek badawczych, należy pamiętać, że miasta rdzeniowe - powiaty grodzkie różnią się powierzchnią. Sprawia to, że w różnym stopniu przejmują suburbanizację i powstające nowe grunty zabudowane i zurbanizowane. Powierzchnia całkowita badanych jednostek administracyjnych nie ulegała większym zmianom. Ewentualne jej zmiany dotyczyły powierzchni gruntów rolnych i leśnych. W badanym okresie powstało kilka nowych miast. Na badanych obszarach zidentyfikowano następujące miejscowości: Michałowo - powiat białostocki w 2009 roku, Stepnicę - powiat goleniowski (województwo zachodniopomorskie) w 2014 roku, Mrozy - powiat miński (województwo mazowieckie) - również w 2014 roku.

W artykule obliczono wskaźnik nazywany produktywnością terenów przemysłowych. Został on obliczony poprzez porównanie wartości sprzedanej przemysłu (sekcje B, C, D, E Polskiej Klasyfikacji Działalności z 2007 roku) z danej jednostki do istniejących tam powierzchni terenów przemysłowych. Należy pamiętać, że wartość sprzedana w danym roku nie uwzględnia inflacji (ceny bieżące) - nie była ona wielka. Wartość sprzedana jest liczona metodą przedsiębiorstw - podmiotu. Może to powodować pewne niedoszacowanie w innych miastach na korzyść np. Poznania czy Warszawy, szczególnie dla spółek z sekcji D - wytwarzanie i zaopatrywanie w energię elektryczną, gaz, parę wodną, gorącą wodę i powietrze do układów (por. rozporządzenie Rady Ministrów z 9 listopada 2012 roku w sprawie programu badań statystycznych statystyki publicznej na rok 2013).

\section{ZMIANY BEZWZGLĘDNE, STRUKTURA GRUNTÓW ZABUDOWANYCH}

\section{ZURBANIZOWANYCH}

Pierwszym omawianym zagadnieniem są zmiany bezwzględne powierzchni gruntów badanych obszarów w podziale na główne kierunki użytkowania gruntów. Ten

\footnotetext{
${ }^{3}$ Do zurbanizowanych terenów niezabudowanych lub w trakcie zabudowy zalicza się grunty:

1. na których rozpoczęto i nie zakończono budowy, w rozumieniu art. 41 ust. 1 ustawy z dnia 7 lipca 1994 r. - Prawo budowlane, powodujące wyłączenie tych gruntów z produkcji rolnej lub leśnej w rozumieniu przepisów ustawy z dnia 3 lutego 1995 r. o ochronie gruntów rolnych i leśnych (Dz.U. z 2013 r. poz. 1205);

2. które w wyniku zabudowy zostały wyłączone z produkcji rolnej lub leśnej, w rozumieniu przepisów ustawy o ochronie gruntów rolnych i leśnych, na których jednak istniejące wcześniej budynki zostały rozebrane, a jednocześnie grunty te przeznaczone są pod zabudowę.
} 
zabieg służy ukazaniu tła przemian przestrzennych w zastosowanych jednostkach badawczych. $\mathrm{W}$ tab. 2. przedstawiono zsumowane powierzchnie głównych kierunków użytkowania gruntów opisywanych w ewidencji i statystyce, w odniesieniu do podobszarów użytych jednostek badawczych. Łączna powierzchnia jednostek badawczych wyniosła w 2014 roku 4715,8 tys. ha. Miasta rdzeniowe z 436,4 tys. ha łącznej powierzchni stanowiły 9,2\% badanych obszarów. Jeśli rozpatrywać poszczególne kierunki użytkowania gruntów, to największą powierzchnię zajęły użytki rolne - blisko $60 \%$, następnie grunty leśne - $28 \%$ oraz zabudowane i zurbanizowane $-10 \%$. Pozostałe tereny i grunty pod wodami stanowią łącznie $5 \%$. W miastach rdzeniowych proporcja ta wyniosła odpowiednio: $30 \%, 20 \%, 43 \%$ i $8 \%$, a na obszarze zewnętrznym razem: $60 \%$, $29 \%, 6 \%$ i 5\%. Jak widać, obszar zewnętrzny wyróżnia się większym udziałem użytków rolnych i gruntów leśnych.

Tab. 2. Kierunki zagospodarowania gruntów na obszarze i w podobszarach jednostek badawczych w tys. ha w 2014 roku

\begin{tabular}{|c|c|c|c|c|c|c|}
\hline \multirow[b]{2}{*}{$\begin{array}{l}\text { Podobszary jednostek } \\
\text { badawczych }\end{array}$} & \multicolumn{6}{|c|}{$\begin{array}{l}\text { Kierunki zagospodarowania gruntów na obszarze jednostek badawczych } \\
\text { w tys. ha }\end{array}$} \\
\hline & 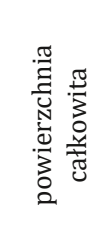 & 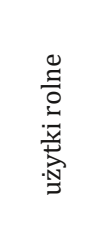 & 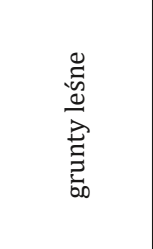 & 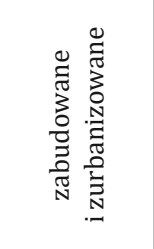 & 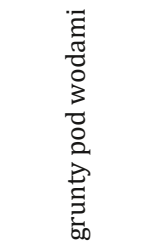 & 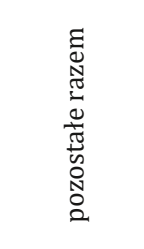 \\
\hline miasta rdzeniowe & $\begin{array}{c}436,4 \\
(100 \%)\end{array}$ & $\begin{array}{c}130,8 \\
(30 \%)\end{array}$ & $85,8(20 \%)$ & $\begin{array}{r}185,9 \\
(43 \%)\end{array}$ & $17,6(4 \%)$ & $16,3(4 \%)$ \\
\hline obszar zewnętrzny razem & $\begin{array}{l}4279,4 \\
(100 \%)\end{array}$ & $\begin{array}{l}2554,8 \\
(60 \%)\end{array}$ & $\begin{array}{l}1243,8 \\
(29 \%)\end{array}$ & $269,5(6 \%)$ & $113,3(3 \%)$ & $97,9(2 \%)$ \\
\hline $\begin{array}{l}\text { miasta w obszarze } \\
\text { zewnętrznym }\end{array}$ & $\begin{array}{c}296,1 \\
(100 \%)\end{array}$ & $\begin{array}{l}120,3 \\
(40 \%)\end{array}$ & $73,9(25 \%)$ & $75,8(26 \%)$ & $17,6(6 \%)$ & $\begin{array}{c}8,6 \\
(3 \%)\end{array}$ \\
\hline $\begin{array}{l}\text { wsie w obszarze } \\
\text { zewnętrznym }\end{array}$ & $\begin{array}{c}3983,3 \\
(100 \%)\end{array}$ & $\begin{array}{l}2434,5 \\
(61 \%)\end{array}$ & $\begin{array}{l}1169,9 \\
(29 \%)\end{array}$ & $193,7(5 \%)$ & $95,7(2 \%)$ & $89,3(2 \%)$ \\
\hline razem & $\begin{array}{l}4715,8 \\
(100 \%)\end{array}$ & $\begin{array}{l}2685,6 \\
(57 \%)\end{array}$ & $\begin{array}{l}1329,6 \\
(28 \%)\end{array}$ & $\begin{array}{c}455,4 \\
(10 \%)\end{array}$ & $130,9(3 \%)$ & $114,2(2 \%)$ \\
\hline
\end{tabular}

Źródło: opracowanie własne

Jeśli przyjrzymy się gruntom zabudowanym i zurbanizowanym oraz ich strukturze w poszczególnych badanych jednostkach, a także w podziale rdzeń - obszar zewnętrzny, widoczny jest znaczny udział terenów pod drogami w obszarze zewnętrznym. Im mniejszy udział miast w obszarze zewnętrznym, tym proporcjonalnie większy udział tych terenów kosztem innych. Można to zaobserwować w przypadku Białegostoku i Lublina, Olsztyna i Kielc (ryc. 3).

Obszary przemysłowe największy udział mają na terenie miast rdzeniowych Krakowa, Szczecina, Bydgoszczy, Trójmiasta, konurbacji śląskiej. We wszystkich rejonach tereny przemysłowe zajmują trzecią lub czwartą pozycję w strukturze, po terenach mieszkaniowych i innych zabudowanych (usługi) oraz drogach. Obszary zewnętrzne 
Ryc. 3. Struktura terenów zabudowanych i zurbanizowanych badanych jednostek w 2014 roku

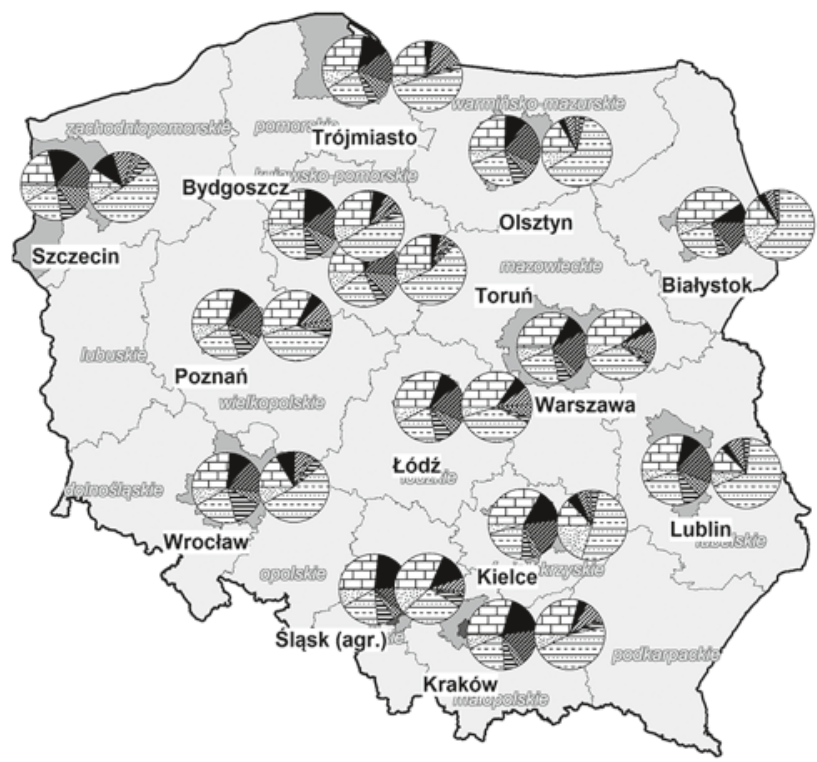

Grunty zabudowane i zurbanizowane Struktura 2014

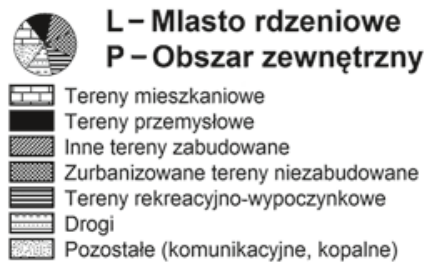

* Śląsk (agr.) - agregacja odpowiadająca częściowo konurbacji górnośląskiej

Źródło: opracowanie własne

Ryc. 4. Zmiany bezwzględne powierzchni w poszczególnych kategoriach użytkowania gruntów w latach 2005, 2009-2014 (ha)

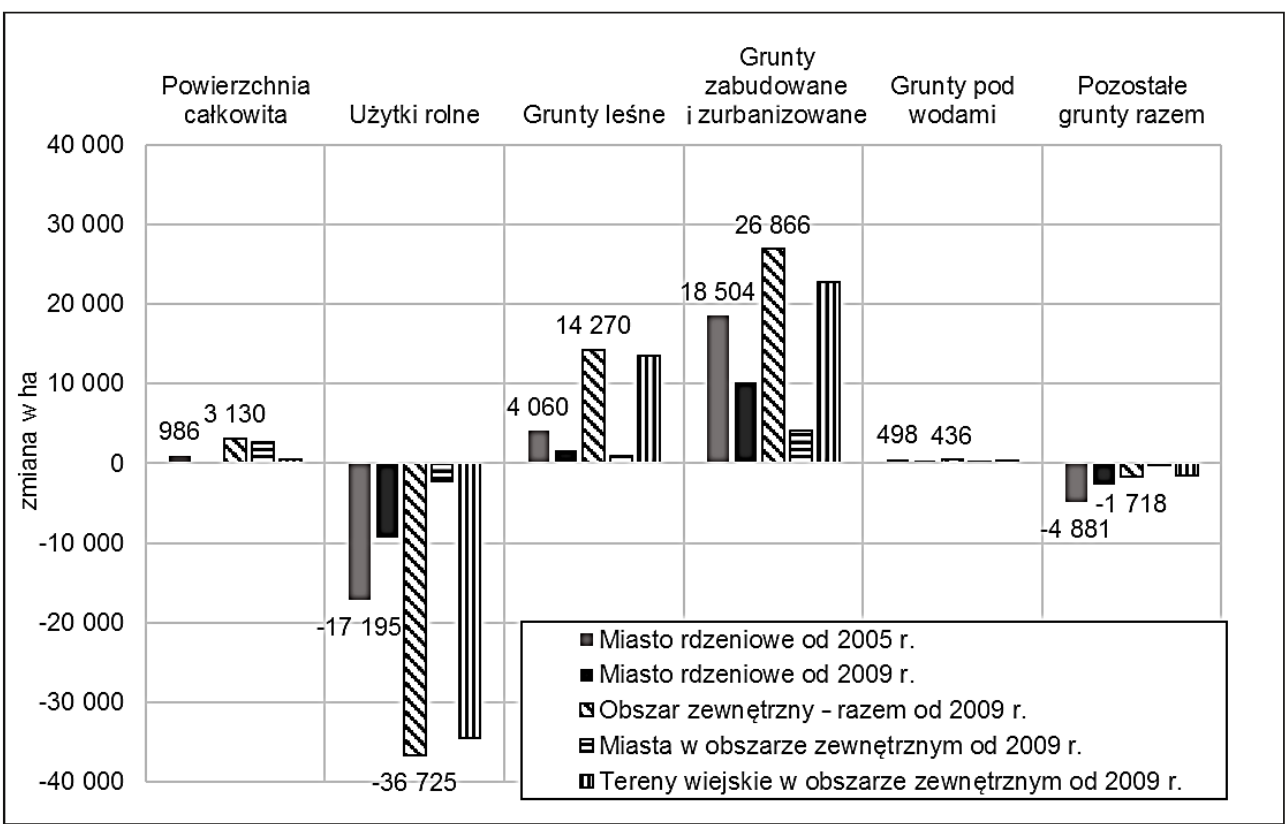

Źródło: opracowanie własne 
Ryc. 5.Zmiany bezwzględne powierzchni w poszczególnych kategoriach użytkowania gruntów zabudowanych i zurbanizowanych w latach 2005, 2009-2014 (ha)

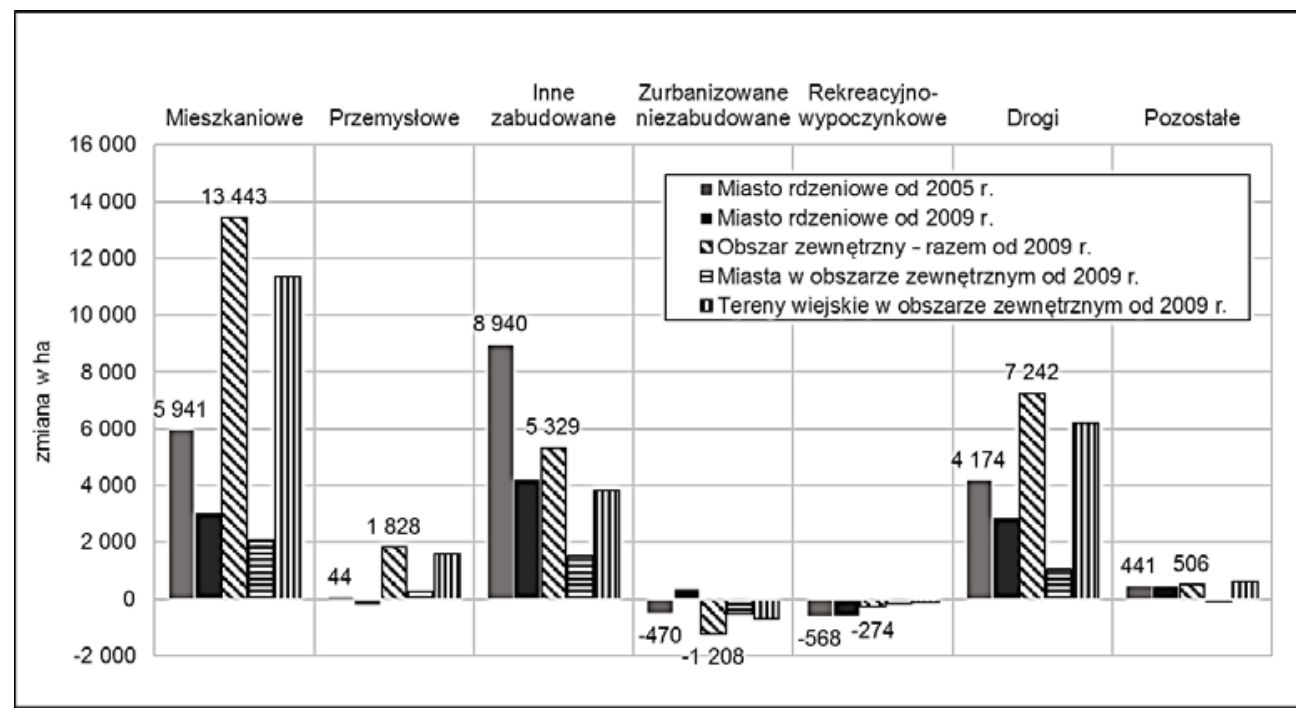

Źródło opracowanie własne

Ryc. 6. Zmiana bezwzględna powierzchni terenów przemysłowych w badanych jednostkach przestrzennych za lata 2009-2014 (ha)

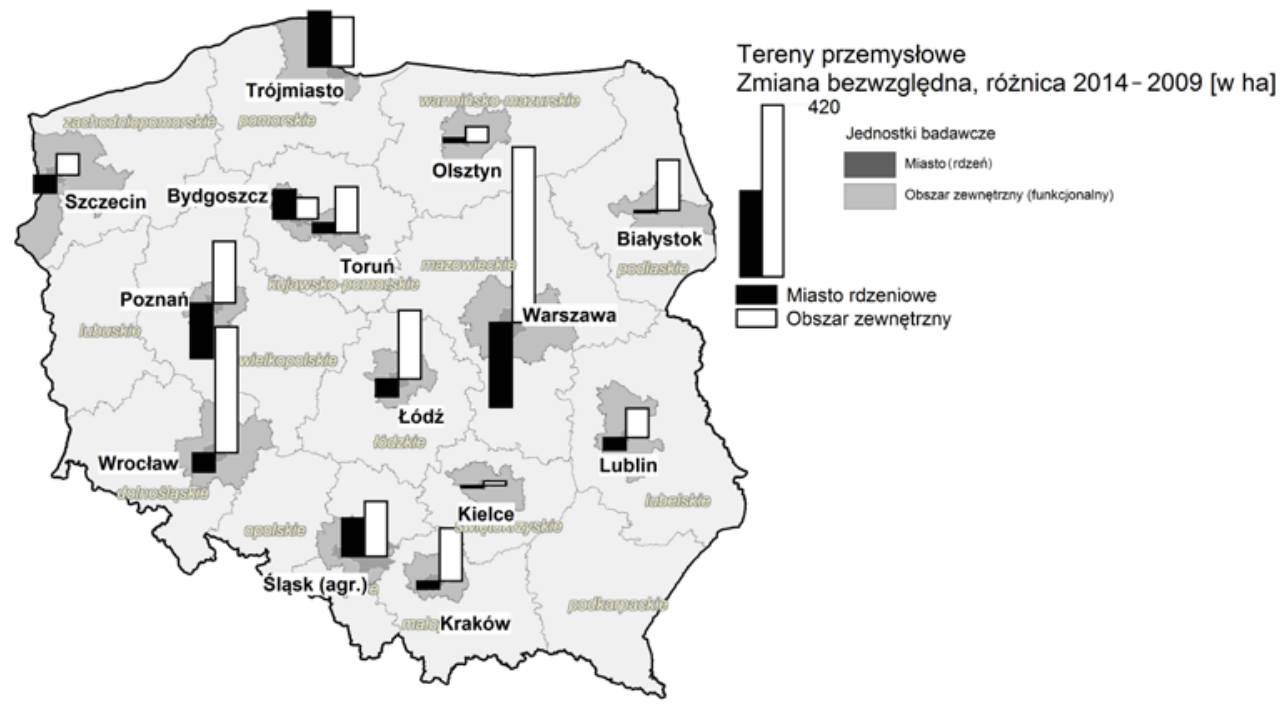

* Śląsk (agr.) - agregacja odpowiadająca częściowo konurbacji górnośląskiej

Źródło: opracowanie własne 
o nieco większym udziale terenów przemysłowych na tle pozostałych charakteryzują Śląsk, Szczecin i Wrocław (15\%). Najmniej takich terenów można spotkać w obszarach zewnętrznych miast wschodnich - Lublina, Białegostoku, Kielc, a także Olsztyna, Warszawy i Łodzi, gdzie przeważają tereny mieszkaniowe. Zmiany powierzchni głównych kategorii użytków w latach 2005, 2009-2014 dla miast rdzeniowych oraz dla obszarów zewnętrznych w latach 2009-2014 łącznie w ujęciu bezwzględnym zaprezentowano na ryc. 4. Zmiany bezwzględne wyrażone w hektarach ukazują kurczenie się powierzchni użytków rolnych zarówno w miastach rdzeniowych, jak i na obszarach otaczających. Powiększyły się za to powierzchnie zajmowane przez grunty zabudowane i zurbanizowane, a także grunty zalesione. Pozostałe kategorie użytkowania gruntów charakteryzowały mniejsze zmiany.

Wśród obszarów zabudowanych i zurbanizowanych znajdują się tereny przemysłowe. Ich bezwzględne zmiany w badanym okresie w hektarach były znacznie mniejsze na tle zmian terenów mieszkaniowych, dróg i innych terenów zabudowanych. W miastach rdzeniowych za lata 2009-2014 zauważyć można ubytek terenów przemysłowych, natomiast w obszarach zewnętrznych - zwiększenie powierzchni o 1828 ha w miastach i we wsiach (ryc. 5).

W relacji do terenów mieszkaniowych i innych zabudowanych rejony przemysłowe wykazały zdecydowanie mniejsze przyrosty. Na ryc. 5 zauważyć można także zmniejszenie powierzchni gruntów zurbanizowanych niezabudowanych, rekreacyjno-wypoczynkowych (należą do nich m.in. ośrodki wczasowe i ogrody działkowe) oraz pozostałych. Po zestawieniu ryc. 4 i 5 można mówić wręcz o pewnej racjonalizacji wykorzystania terenów.

Wyodrębniając z poszczególnych kategorii użytkowania terenów grunty przemysłowe i ukazując je dla wszystkich badanych jednostek w postaci kartodiagramu zmian bezwzględnych, uzyskano obraz zmian za lata 2009-2014 zaprezentowany na ryc. 6. Spośród 14 miast rdzeniowych w dziewięciu zmniejszyła się powierzchnia obszarów przemysłowych. Zmiana ta była najwyraźniejsza w Warszawie (-197 ha), Poznaniu (-129 ha), Łodzi i Szczecinie (-43 ha), dotyczyła ponadto Lublina, Krakowa i Wrocławia oraz w nieznacznym stopniu Kielc i Białegostoku. Przyrosty powierzchni terenów przemysłowych za lata 2009-2014 obserwuje się na obszarze Trójmiasta (129 ha) oraz konurbacji śląskiej, Bydgoszczy i Torunia. Co do obszarów zewnętrznych miast rdzeniowych, to we wszystkich przypadkach zanotowano zwiększenie powierzchni przemysłowych. Największy taki przyrost dokonał się w obszarze zewnętrznym Warszawy (420 ha), Wrocławia, Poznania, Łodzi i Krakowa, a relatywnie mniejszy - w Kielcach (11 ha), Olsztynie, Szczecinie i Bydgoszczy.

\section{ZMIANY WZGLĘDNE}

Modyfikacje względne powierzchni wyrażają dynamikę zmian. Wpływ na wartości dynamiki ma podstawa - bazowa powierzchnia, od której liczona jest zmiana w wyrażeniu procentowym. Na ryc. 7. przedstawiono zmiany względne powierzchni gruntów w poszczególnych kategoriach ich użytkowania w latach 2005, 20092014. Na tym tle zaprezentowano następnie zmiany względne powierzchni terenów 
Ryc. 7. Względne zmiany powierzchni w poszczególnych kategoriach użytkowania gruntów w latach 2005, 2009-2014

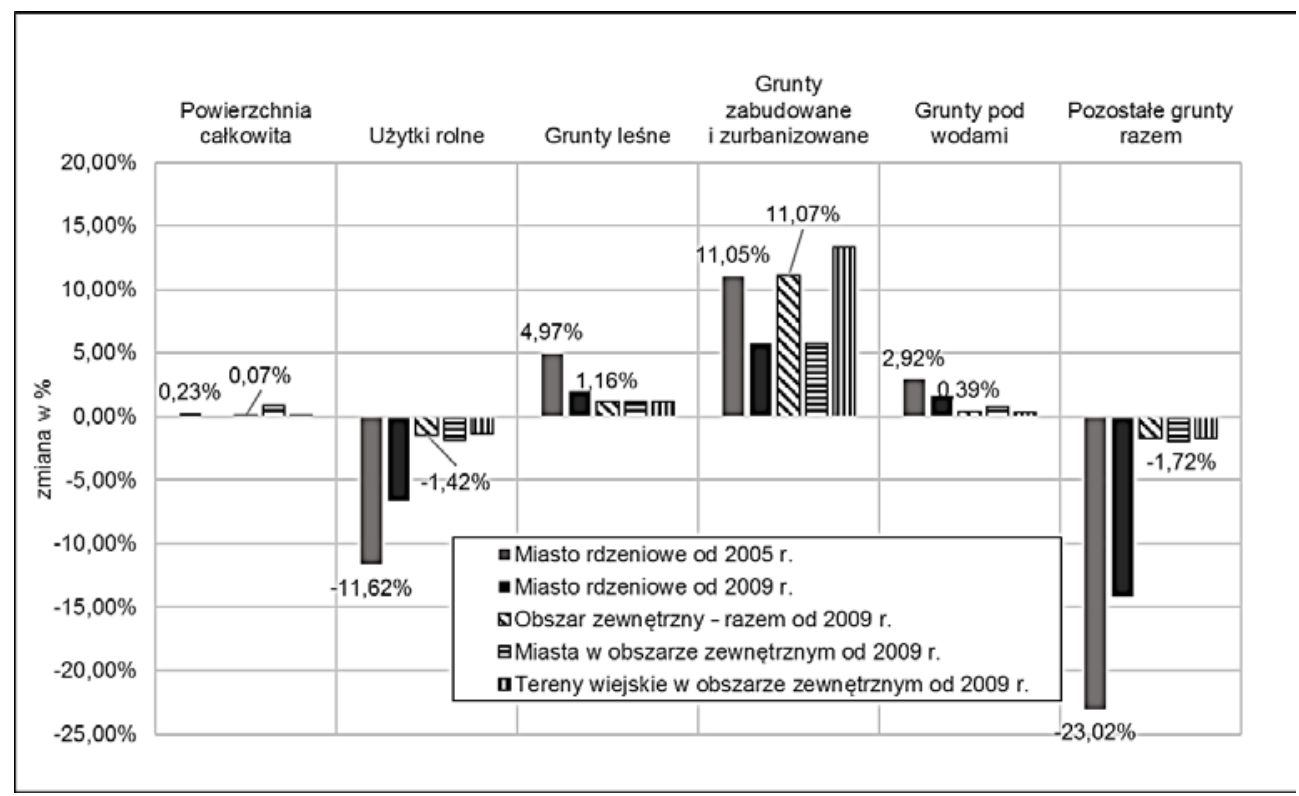

Źródło: opracowanie własne

Ryc. 8. Względne zmiany powierzchni w poszczególnych kategoriach użytkowania gruntów zabudowanych i zurbanizowanych w latach 2005, 2009-2014 (\%)

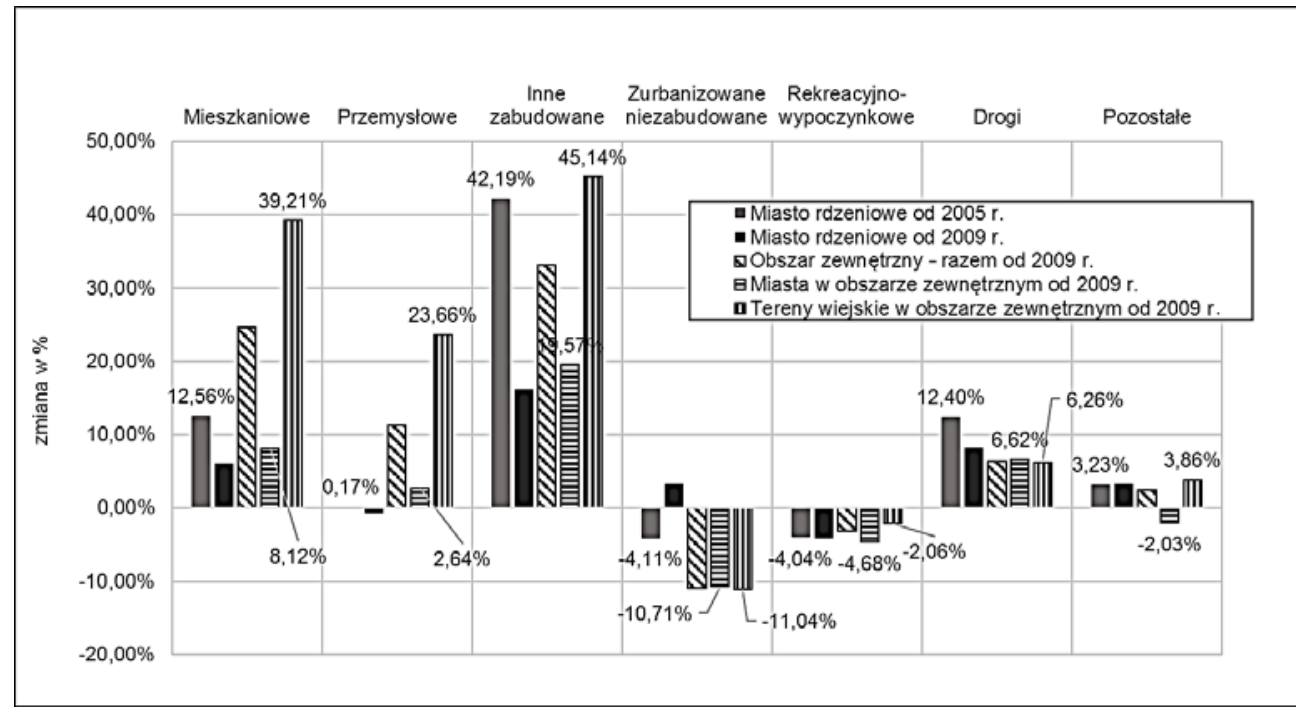

Źródło: opracowanie własne 
przemysłowych - por. ryc. 8. Powierzchnia użytków rolnych w badanych jednostkach, zarówno dla obszarów miast rdzeniowych, jak i otaczających je powiatów, zmniejszyła się, z większą dynamiką w miastach rdzeniowych: pomiędzy 2005 a 2014 rokiem o -11,6\%, natomiast dla obszarów zewnętrznych za lata 2009-2014 o-1,4\%. Analizując ryc. 7., należy zwrócić uwagę na kategorię gruntów zabudowanych i zurbanizowanych, gdzie przyrost powierzchni był dwukrotnie wyższy na obszarach zewnętrznych niż w miastach rdzeniowych.

Po oddzieleniu miast w obszarze zewnętrznym od terenów wiejskich te ostatnie charakteryzuje większa zmiana powierzchni gruntów zabudowanych o 12\% w stosunku do 5\%. Grunty w kategorii pozostałe, o znacznie mniejszej powierzchni wśród kierunków użytkowania gruntów, zmniejszyły się we wszystkich badanych obszarach ujętych razem. Najwyraźniej ta zmiana przebiegała w miastach rdzeniowych (-23\% od 2005 roku).

Zmiany względne, odniesione do gruntów zabudowanych i zurbanizowanych oraz poszczególnych kategorii terenów w nich ujętych, przedstawiono na ryc. 8. Na tej podstawie można zauważyć, że największą dynamiką in plus charakteryzowały się grunty inne zabudowane. Od 2005 do 2014 roku zmiana dla miast rdzeniowych wyniosła 42\%, a od 2009 do 2014 roku - 17\%. Obszary zewnętrzne miast zwiększyły o 33\% powierzchnię tych gruntów, przy czym w rozdzieleniu na miasto i wieś dynamika po stronie wsi była jeszcze większa (45\%). W analogicznym okresie tereny mieszkaniowe w obszarach zewnętrznych powiększyły się o $24,6 \%$, w tym w miastach rdzeniowych o 5\%, natomiast na terenach wiejskich - o blisko 40\%. Dla miast rdzeniowych przyrost powierzchni mieszkaniowych był niższy, wyniósł bowiem ok. 5\%, a od 2005 do 2014 roku - 12,5\%. Dodatnią dynamiką w latach 2009-2014, na poziomie 5-6\%, charakteryzowały się także powierzchnie zajęte przez drogi i były to zmiany prawie identyczne dla całych badanych jednostek.

Tereny zurbanizowane niezabudowane zmniejszyły swoją powierzchnię na obszarach zewnętrznych o blisko $11 \%$ (na terenach wiejskich i w miastach podobnie). W granicach miast rdzeniowych w okresie od 2009 do 2014 roku nieznacznie powiększyły się o wartość 3,3\%. W porównaniu do lat 2005 i 2014 było ich jednak mniej o -4,1\%. Tereny przemysłowe dla rozpatrywanych łącznie miast rdzeniowych praktycznie nie zmieniły swojej powierzchni, w latach 2005-2014 wzrost wyniósł 0,17\%. Można zauważyć bardzo niewielkie zmniejszenie tych terenów w latach 2009-2014 (-0,7\%). W przypadku obszarów zewnętrznych razem widoczne jest zwiększenie powierzchni przemysłowych o 11,3\%, a w podziale na obszary miast i wsi odpowiednio 2,6\% i 23\%.

Względne zmiany powierzchni terenów przemysłowych w latach 2009-2014 zobrazowano w postaci kartodiagramu (ryc. 9), z uwzględnieniem wszystkich jednostek badawczych i w podziale na miasto rdzeniowe - obszar zewnętrzny. W nawiązaniu do kartodiagramu ukazującego zmiany bezwzględne (różnice w hektarach) spośród 14 badanych jednostek w dziewięciu widać zmniejszenie powierzchni terenów przemysłowych. Ma ono różne nasilenie, najbardziej widoczne w Poznaniu $(-10,6 \%)$ i Warszawie $(-7,1 \%)$, Lublinie $(-4,6 \%)$, Łodzi i Wrocławiu $(-3,3 \%)$. W pozostałych przypadkach (Szczecin, Kraków, konurbacja śląska, Białystok, Kielce) jest to poniżej 3\%.

W Trójmieście tereny przemysłowe w badanym okresie powiększyły się o 7,7\%, o nieco zaś mniej w Bydgoszczy (6,5\%), Toruniu $(4,8 \%)$, Olsztynie $(3,1 \%)$ i konurbacji śląskiej $(0,8 \%)$. Wszystkie obszary zewnętrzne otaczające miasta rdzeniowe 
odnotowały względne przyrosty powierzchni terenów przemysłowych, zmiana ta była bardzo różna, w zależności od badanej jednostki. W przypadku obszarów zewnętrznych Szczecina, Kielc oraz konurbacji śląskiej zmiana wyniosła od 1,7\% do 4\%. W pozostałych przypadkach zmiany były wyższe, szczególnie w obszarze zewnętrznym Torunia (43\%), Białegostoku (38\%), Krakowa (32\%), Lublina (21\%). W pozostałych miastach (Warszawa, Poznań, Łódź, Wrocław, Bydgoszcz, Trójmiasto) zmiana in plus wyniosła kilkanaście procent, w przedziale od $11 \%$ do $18 \%$.

Ryc. 9. Zmiana względna powierzchni terenów przemysłowych w badanych jednostkach przestrzennych za lata 2009-2014 (ha)

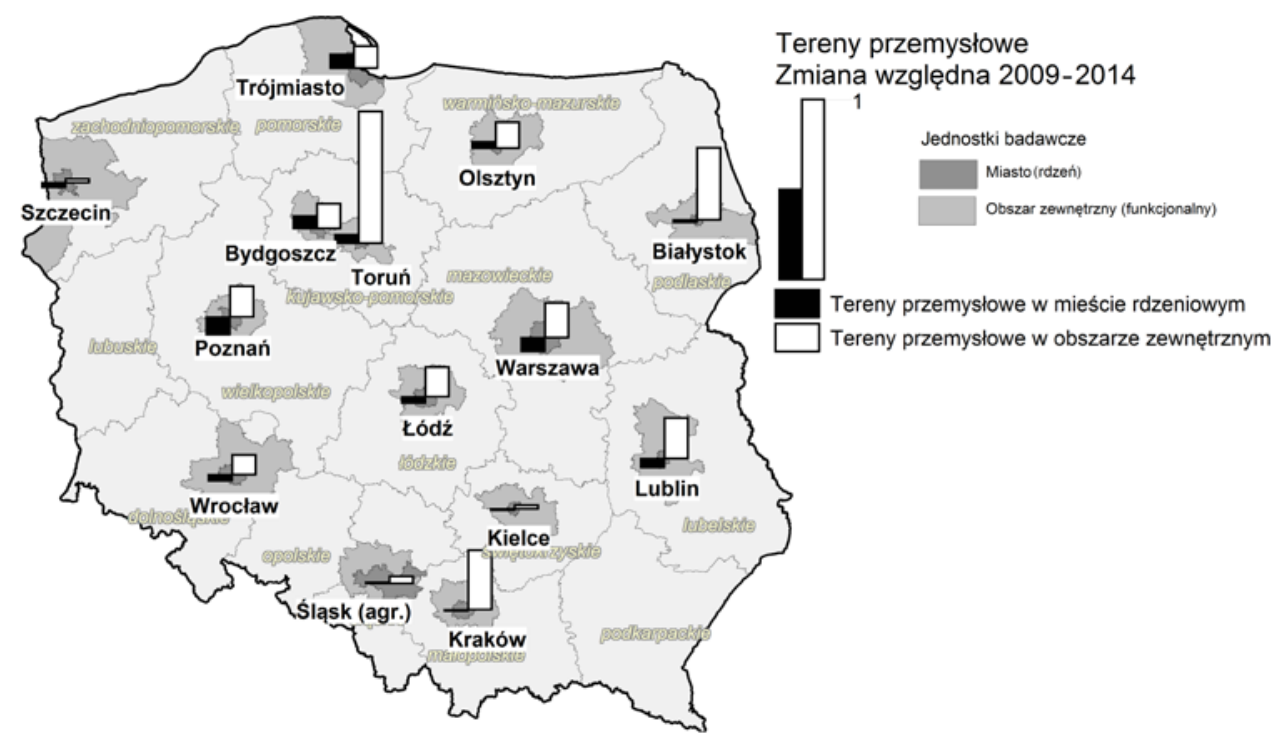

* Śląsk (agr.) - agregacja odpowiadająca częściowo konurbacji górnośląskiej

Źródło: opracowanie własne

\section{ZMIANY W STRUKTURZE UŻYTKOWANIA GRUNTÓW I PRODUKTYWNOŚĆ TERENÓW PRZEMYSŁOWYCH}

Zmiany w strukturze to zmiany w pewnej zamkniętej całości, którą w przypadku badanych jednostek - miast wraz z ich bezpośrednim otoczeniem - stanowią powierzchnie poszczególnych kierunków użytkowania gruntów. Pod uwagę wzięto także tereny przemysłowe i ich relacje $\mathrm{w}$ odniesieniu do pozostałych terenów $\mathrm{w}$ kategorii grunty zabudowane i zurbanizowane, do której zostały przypisane. Ryc. 10. przedstawia zbiorcze zestawienie zmian struktury dla kierunków użytkowania gruntów w badanych jednostkach odpowiadających obszarom metropolitarnym. 
Najwyraźniejsze przesunięcia w strukturze widoczne są pomiędzy gruntami rolnymi a zabudowanymi i zurbanizowanymi, można powiedzieć wręcz, że zmiany te są odwrotnie proporcjonalne. Największe zmiany obserwowane są dla miast rdzeniowych - powiatów grodzkich i miast w ich otoczeniu. W latach 2005-2014 grunty zabudowane i zurbanizowane zwiększyły swój udział w strukturze powierzchni miast rdzeniowych o 4,15\%, natomiast w latach 2009-2014 - o 2,3\%. Interpretując dane o zmianach w strukturze, należy mieć na uwadze, że są one wypadkową zmian w pozostałych elementach struktury, w tym przypadku w pozostałych kategoriach użytkowania gruntów. Suma zmian w strukturze dla danego podobszaru wynosić będzie zero.

Ryc. 10. Zmiany w strukturze głównych kategorii użytkowania gruntów dla badanych jednostek razem w latach 2005, 2009-2014

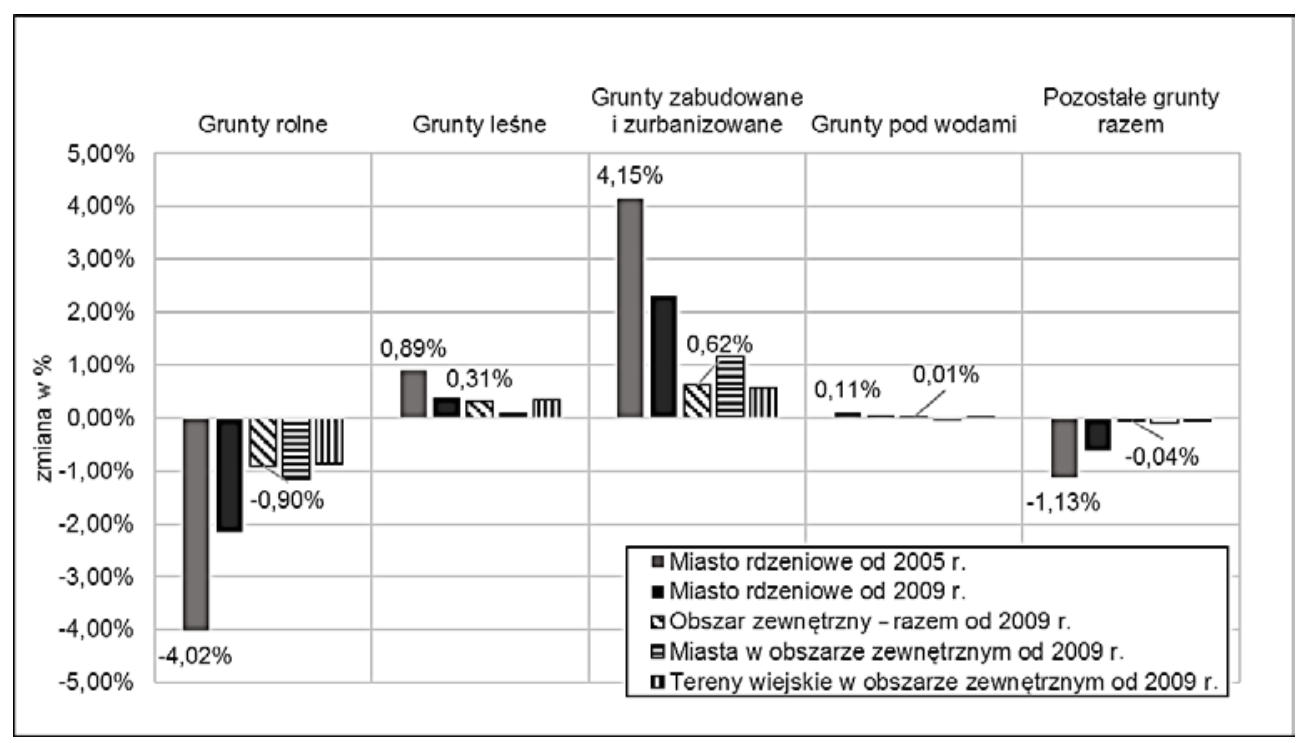

Źródło: opracowanie własne

W odniesieniu do zmian w strukturze gruntów zabudowanych i zurbanizowanych zauważyć można (ryc. 11), że tereny zajęte przez mieszkania (domy, osiedla z otoczeniem) zwiększyły swój udział w strukturze obszarów zewnętrznych o 2,7\%. Na obszarach wiejskich w otoczeniu miast rdzeniowych udział w strukturze zwiększył się o blisko 4\%. Inne tereny zabudowane w latach 2009-2014 zwiększyły swój udział proporcjonalnie we wszystkich podobszarach badanych jednostek - na poziomie 1,3\%. Na tym tle widoczne jest zmniejszenie udziału w strukturze terenów przemysłowych. Jedynie na obszarach wiejskich w otoczeniu miast rdzeniowych nieznacznie (o 0,3\%) zwiększył się udział powierzchni tych terenów wśród gruntów zurbanizowanych. W miastach rdzeniowych, zarówno od 2005, jak i od 2009 roku, widoczne jest zmniejszenie udziału terenów przemysłowych w strukturze. Niewielkie zmiany w strukturze dotyczyły także gruntów zurbanizowanych niezabudowanych - zmniejszenie udziału o mniej niż 1\%. Podobnie było też w przypadku terenów rekreacyjno-wypoczynkowych. 
Ryc. 11. Zmiany w strukturze gruntów zurbanizowanych i zabudowanych dla badanych jednostek razem w latach 2005, 2009-2014

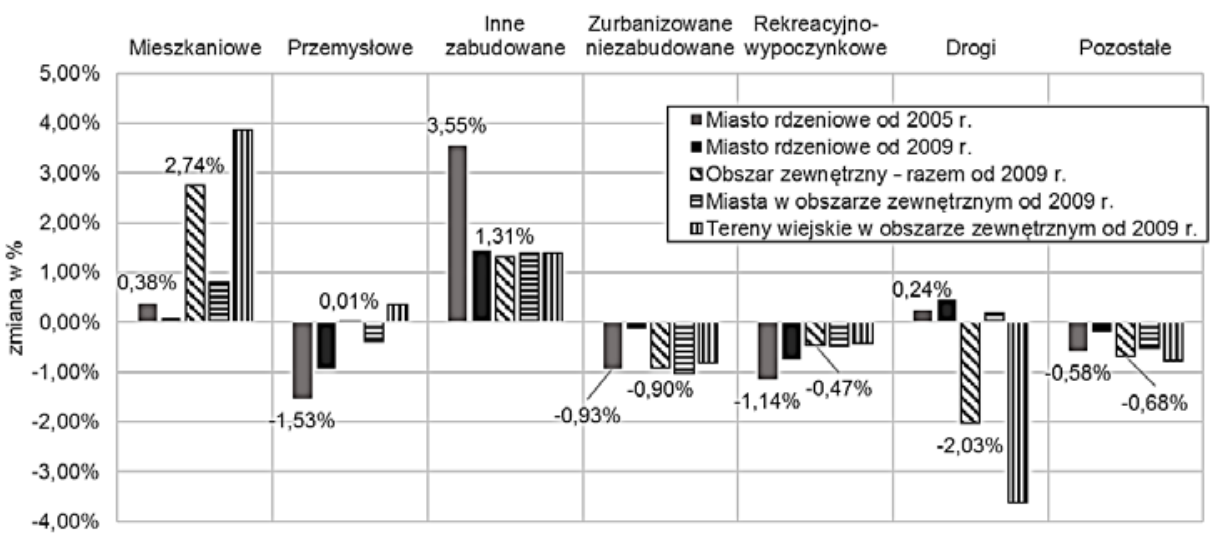

Źródło: opracowanie własne

Ryc. 12. Produkcja sprzedana przemysłu w zł w przeliczeniu na 1 ha terenów przemysłowych w latach 2009 i 2014

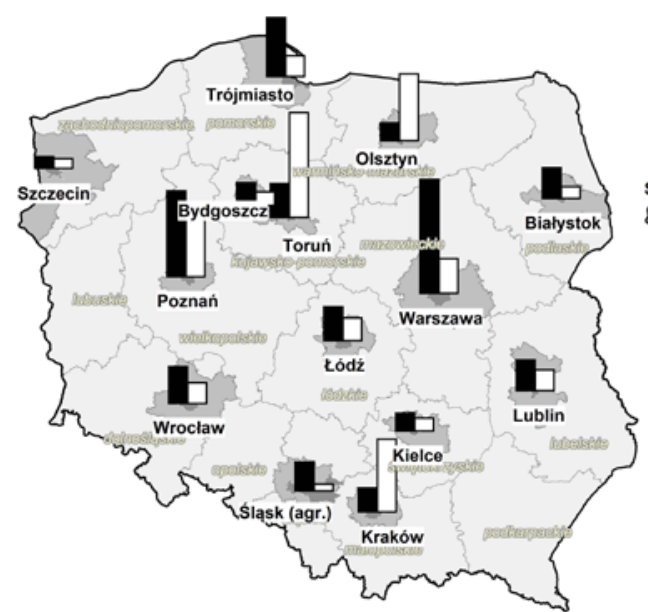

Produkcja sprzedana przemysłu (podm. $>9$ ) zł na 1 ha terenów przemysłowych

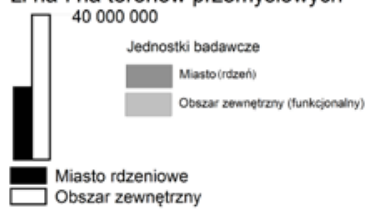

Źródło: opracowanie własne

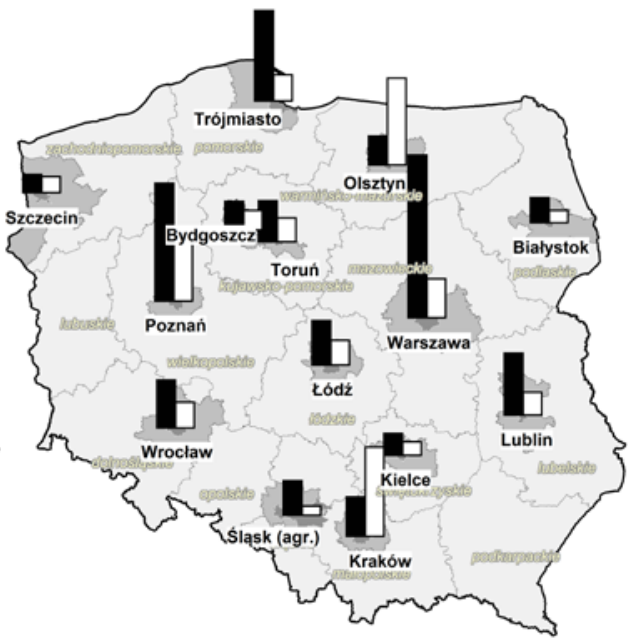

Produkcja sprzedana przemysłu (podm. $>9$ ) zł na 1 ha terenów przemysłowych

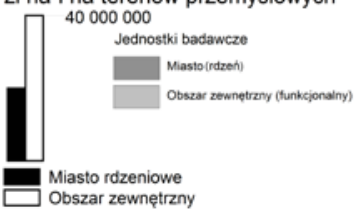


Niewielkie przyrosty udziału w strukturze odnotowuje się w miastach rdzeniowych i miastach obszarów zewnętrznych w kategorii terenów zajętych przez drogi, natomiast na obszarach wiejskich $\mathrm{w}$ otoczeniu miast rdzeniowych wystąpiły spadki udziału w strukturze o 3,6\%.

Na podstawie danych o powierzchni terenów przemysłowych oraz wartości produkcji sprzedanej przemysłu (PKD z 2007 roku, sekcje B, C, D, E) przedsiębiorstw zatrudniających powyżej dziewięciu osób obliczono wskaźnik produkcyjności 1 ha terenów przemysłowych dla miast rdzeniowych i otaczających je powiatów grodzkich. Dokonano tego dla lat 2009 i 2014, ze względu na brak danych za 2014 rok o produkcji sprzedanej wykorzystano dane z 2013 roku. Zobrazowaniem tego są dwa kartodiagramy - ryc. 12 .

Na pierwszej z rycin zaobserwować można, że w 2009 roku w 11 przypadkach tereny przemysłowe miały większą produktywność niż w obszarach zewnętrznych. Różnice te są znaczne w przypadku konurbacji śląskiej $(7,7 \mathrm{mln}$ zł/ha do 1,9 mln zł/ha), a także Warszawy, gdzie zanotowano najwyższą produktywność z 1 ha powierzchni przemysłowych (30 mln zł/ha). Dużą produktywnością charakteryzowały się również powierzchnie przemysłowe w Poznaniu (22,6 mln zł/ha) oraz Trójmieście (15,6 mln zł/ha). Najmniej produktywne powierzchnie przemysłowe w znaczeniu pieniężnym charakteryzowały w 2009 roku Szczecin (3,1 mln zł/ha), Bydgoszcz (3,8 mln zt/ha), Olsztyn (4,7 mln zł/ha) i Kielce (4,8 mln zł/ha).

Obszary zewnętrzne w badanym roku miały niższe wartości produkcji sprzedanej na 1 ha terenów przemysłowych, wyjątkiem były powiaty toruński i olsztyński oraz obszar zewnętrzny Krakowa (powiaty krakowski i wielecki). Co ciekawe, w granicach miast Krakowa i Olsztyna znajdują się duże powierzchniowo zakłady przemysłowe, tj. huta Mittal Steel Polska oraz Michelin Polska. Niewielką wartość sprzedaną przemysłu wykazują obszary zewnętrzne konurbacji śląskiej. W 2014 roku widoczny jest wzrost produktywności 1 ha powierzchni przemysłowych prawie we wszystkich przypadkach dla miast rdzeniowych, wyjątek stanowi Białystok (-18\%), a także dla obszarów zewnętrznych - tu wyjątkiem jest obszar zewnętrzny Torunia ${ }^{4}$. Generalnie, w porównaniu z 2009 rokiem, proporcje pomiędzy poszczególnymi jednostkami badawczymi utrzymały się na podobnym poziomie. Najmniejszą produktywność rdzenia i obszarów zewnętrznych w przeliczeniu na 1 ha powierzchni przemysłowych mają Szczecin, Kielce, Bydgoszcz i Białystok. Za lata 2009-2014 największe zmiany dodatnie wystąpiły w miastach rdzeniowych - w Warszawie, Poznaniu Trójmieście i Lublinie ${ }^{5}$.

Po porównaniu zmiany stanu obliczonego wskaźnika wartości produkcji sprzedanej przemysłu z lat 2009 i 2014 dla potraktowanych łącznie miast rdzeniowych i otaczających je obszarów zewnętrznych okazuje się, że dla rdzeni wzrost wskaźnika (średnia arytmetyczna) wyniósł 39\%, natomiast dla otoczenia - 18\%. Produkcja sprzedana przemysłu wyrażona kwotowo (w mln zł) w większości przypadków była wyraźnie wyższa w miastach rdzeniowych, jedynie w Szczecinie, Wrocławiu i Olsztynie w te proporcje były odwrotne.

\footnotetext{
${ }^{4}$ Problemy firmy Sharp, Orion i Sumika z branży elektronicznej.

${ }^{5}$ Dla powiatu lubartowskiego w obszarze zewnętrznym Lublina brakowało danych o wartości sprzedanej przemysłu.
} 


\section{WNIOSKI}

Zaprezentowane w artykule informacje o kierunkach użytkowania gruntów w badanych jednostkach ukazują powiększanie się powierzchni terenów zabudowanych i zurbanizowanych w miastach rdzeniowych i otaczających je obszarach zewnętrznych. Zwiększenie powierzchni gruntów zabudowanych i zurbanizowanych przebiegało szybciej w obszarach zewnętrznych, w szczególności na wsi. W efekcie kurczyły się powierzchnie gruntów rolnych. Potwierdza się w ten sposób ogólnie znana teza o urbanizacji w dużych miastach i ich bezpośrednim otoczeniu - suburbanizacji. Te dwa procesy zachodzą głównie w związku ze zwiększeniem powierzchni mieszkaniowych, dróg i innych terenów zabudowanych. Do tych ostatnich zaliczane są przestrzenie publiczne i usługowe oraz wielkopowierzchniowe sklepy i ich zaplecze.

Na tle procesów urbanizacyjnych tereny przemysłowe wykazują mniejsze zmiany zajmowanych powierzchni. Szczególnie widoczne jest to w relacji do terenów mieszkaniowych i innych zabudowanych. Ujmując razem wszystkie miasta rdzeniowe, tereny przemysłowe praktycznie nie zwiększają powierzchni w badanych latach. Natomiast w przypadku wszystkich obszarów zewnętrznych, w szczególności wiejskich, notuje się powiększenie powierzchni terenów przemysłowych. Jest ono stosunkowo niewielkie, tak że w strukturze gruntów zabudowanych i zurbanizowanych jedynie na wspomnianych obszarach wiejskich nieznacznie zwiększył się ich udział.

Powróćmy do części koncepcyjnej artykułu i przedstawionego bilansu terenów przemysłowych. Najodpowiedniejszym uogólnieniem do badanych jednostek jest przypadek piąty $(-++)$ z tab. 1 - kombinacja na powiększanie się terenów przemysłowych w otoczeniu miast rdzeniowych. Jeśli przyjąć, że bilans powierzchni odpowiada rzeczywistym zmianom funkcji przemysłowych w miastach, to można mówić o deindustrializacji w rdzeniu na rzecz otoczenia. W kontekście zaprezentowanych $\mathrm{w}$ artykule zagadnień teoretycznych i wyników potwierdzają się obserwacje dotyczące deindustrializacji miast rdzeniowych. Studialne przeliczenia wartości sprzedanej przemysłu na 1 ha terenów przemysłowych dla 2009 i 2014 roku ukazały generalnie większą produktywność tych rejonów w rdzeniu (kilka wyjątków). Porównanie stanu z badanych lat pokazuje, że produktywność 1 ha terenów przemysłowych rośnie szybciej niż w ich otoczeniu. Dane nie gwarantują dużej precyzji (metoda przedsiębiorstw), wskazują jednak na interesujący kierunek badań dotyczący hierarchicznego filtrowania w dół w wielkich miastach w Polsce i ich otoczeniu.

\section{Literatura}

\section{References}

Bachmann, M. (2003). Enquiry of Enterprises, Report of the EU research project COMET. Berlin. Chojnicki, Z. (1988). Koncepcja terytorialnego systemu społecznego. Przegląd Geograficzny, $60(4), 502-503$.

Domański, R. (2004). Geografia społeczno-ekonomiczna. Ujęcie dynamiczne. Warszawa: PWN.

Domański, R. (2007). Gospodarka przestrzenna. Podstawy teoretyczne. Warszawa: PWN.

Forman, R.T. (2008). Urban Regions, Ecology and Planning Beyond the City. Cambridge, New York, Melbourne, Madrid, Cape Town, Singapore, São Paulo: Cambridge University Press.

Georgescu-Roegen, N. (1972). The entropy law and the economic process. Cambridge. 
Kafka, K. (2012). Obszary metropolitalne w krajowych i regionalnych dokumentach planistycznych. W: Z. Ziobrowski, W. Jarczewski, K. Kafka. Modele zarządzania gospodarkq przestrzennq $w$ obszarach metropolitalnych $i$ aglomeracjach. Kraków: Instytut Rozwoju Miast, 74-86.

Mariotti, I. (2005). Firm relocation and regional policy. A focus on Italy, the Netherlands and The United Kingdom. Utrecht/Groningen: Royal Dutch Geographical Society, Department of Spatial Sciences University of Groningen.

Moriarty, B.M. (1983). Hierarchies of Cities and the Spatial Filtering of Industrial Development. Papers of the Regional Science Association, 53, 59-82.

Park, R.E., Burgess, E.W., McKenzie, R.D. (1925). The City. Chicago and London: The University of Chicago Press.

Rowthorn, R., Ramaswamy, R. (1997) (2016, 18 stycznia). Deindustrialization: Causes and Implications. International Monetary Fund. Pozyskano z https://www.imf.org/external/ pubs/ft/wp/wp9742.pdf

Rozporządzenie Ministra Rozwoju Regionalnego i Budownictwa z dnia 29 marca 2001 r. w sprawie ewidencji gruntów i budynków (Dz.U. z 2001 r. nr 38 poz. 454).

Rozporządzenie Rady Ministrów z dnia 9 listopada 2012 r. w sprawie programu badań statystycznych statystyki publicznej na rok 2013 (Dz.U. z 2012 r. poz. 1391).

Staszewska, S., Marcinowicz, D. (2006). Struktura funkcjonalno-przestrzenna wybranych terenów przemysłowych Poznania. Prace Komisji Geografii Przemysłu Polskiego Towarzystwa Geograficznego, 9, 74-82.

Sztaba, J. (2013). Rewitalizacja szansą dla regionów poprzemysłowych. Studia i Materiały Wydziału Zarządzania i Administracji Uniwersytetu Jana Kochanowskiego w Kielcach, 109-119.

Śleszyński, P. (2013). Delimitacja miejskich obszarów funkcjonalnych stolic województw. Przegląd Geograficzny, 85(2), 173-197.

Ustawa z dnia 17 maja 1989 r. Prawo geodezyjne i kartograficzne (Dz.U. z 1989 r. nr 30 poz. 163).

Węcławowicz, G., Łotocka, M., Baucz, A. (2010). Rozwój miast w Polsce. Raport wprowadzający Ministerstwa Rozwoju Regionalnego. Warszawa: Ministerstwo Rozwoju Regionalnego.

Wierzchowski, M. (2009). Zagospodarowanie gruntów w Polsce stan w dniu 1.01.2009 roku. Kraków: Instytut Rozwoju Miast.

Wyłączanie gruntów z produkcji rolniczej i jego skutki dla ewidencji podatkowej w gminach w latach 2007-2012 (2012). Warszawa: Najwyższa Izba Kontroli.

Zagajewski, B. (2013). Zastosowanie teledetekcji do oceny stanu zagospodarowania przestrzennego w Polsce. Biuletyn Komitetu Przestrzennego Zagospodarowania Kraju, 252, 13-29.

Jacek Rudewicz, dr inż., Uniwersytet Szczeciński, Wydział Nauk o Ziemi. Jest adiunktem w Katedrze Badań Miast i Regionów. Ukończył kierunek geografia ze specjalnością geografia społeczno-ekonomiczna, kierunek zarządzanie i marketing oraz ekonomia. Obronił doktorat pt. „Rozwój zrównoważony wielkich miast w Polsce”. W pracy naukowej zajmuje się studiami miejskimi, rozwojem zrównoważonym, rozwojem regionalnym, teorią systemów, ekonomicznymi aspektami turystyki.

Jacek Rudewicz, Ph.D., Eng., University of Szczecin, Faculty of Geosciences. He graduated geography with specialization in socioeconomic geography, holds also a degree in management and marketing and economics. Is an assistant professor in Regional and Urban Studies Unit. He defended Ph.D. thesis entitled „Sustainable development of the Polish major cities". Hisresearch interests focus on wide urban studies, sustainable development, regional development, systems theory and economic aspects of tourism.

\section{Adres/address:}

Uniwersytet Szczeciński

Katedra Badań Miast i Regionów

ul. Adama Mickiewicza 18, 70-383 Szczecin, Polska

e-mail: rudewicz@univ.szczecin.pl 